Vol. 45, N. 1 : pp. 97 - 106, March, 2002

ISSN 1516-8913 Printed in Brazil

BRAZILIAN ARCHIVES OF BIOLOGY AND TECHNOLOGY

AN INTERNATIONAL JOURNAL

\title{
Somatic Embryogenesis in Parana Pine (Araucaria angustifolia (Bert.) O. Kuntze)
}

\author{
André Luis Wendt dos Santos ${ }^{1}$, Vanildo Silveira ${ }^{1}$, Neusa Steiner ${ }^{1}$, Mário Vidor ${ }^{2}$ and Miguel \\ Pedro Guerra ${ }^{1 *}$ \\ ${ }^{I}$ Laboratório de Fisiologia do Desenvolvimento e Genética Vegetal, Departamento de Fitotecnia, Centro de \\ Ciências Agrárias, Universidade Federal de Santa Catarina (UFSC), Caixa Postal 476, CEP 88040-900, \\ Florianópolis-SC, Brazil. ${ }^{2}$ Estação Experimental de Lages, Empresa de Pesquisa Agropecuária e Difusão de \\ Tecnologia de Santa Catarina S.A. (EPAGRI), Caixa Postal 181, CEP 88502-970, Lages - SC, Brazil
}

\begin{abstract}
Embryogenic cultures of Araucaria angustifolia were induced from dominant and non-dominant zygotic embryos excised from immature seeds proceeding from three different genotypes and five harvest dates. Zygotic embryos were inoculated in inductive culture medium LP and BM supplemented with or without plant growth regulators 2,4$D(5 \mu M), B A(2 \mu M)$ and Kin $(2 \mu M)$. The genotype of the mother tree and the developmental explant stage affected the induction frequency. In the maintenance phase, embryogenic cultures were maintained at continuous repetitive cell cycles every 20 days in semi-solid or liquid medium. In the maturation phase the culture medium was supplemented with different types and levels of growth regulators, osmotic agents, carbohydrates and derived. Embryogenic cultures inoculated in culture medium supplemented with PEG 3350 (6 and 9\%), maltose (6 and 9\%), plus BA and Kin (1 $\mu \mathrm{M}$ each) resulted in the progression of somatic embryos to globular and torpedo developmental stages.
\end{abstract}

Key words: Araucaria angustifolia, conifer, somatic embryogenesis, Picea abies, embryo maturation, Pinus sp.

\section{INTRODUCTION}

Araucaria angustifolia (Bert.) O. Kuntze is a conifer species of the Araucariaceae family. During most part of the $20^{\text {th }}$ century, $A$. angustifolia was the most important woody species from South Brazil. Nowadays, only relicts with this species are found, representing from $1 \%$ (Lima \& Capobianco, 1997) to about 2\% (Guerra et al., 1999) of the original area. Therefore, it is necessary to development the technologies for conservation and genetic improvement of this subtropical conifer species.
Biotechnology based techniques provide efficient methods of micropropagation, genetic improvement, and for germplasm conservation of tropical and subtropical trees (Litz et al., 1997). Among these, micropropagation technique that has become widely utilized in forest biotechnology is somatic embryogenesis. Somatic embryogenesis involves the development of somatic cells into embryos, which often proceeds through morphological stages resembling zygotic embryogenesis (Dong \& Dunstan, 1999). In conifers, somatic embryogenesis and plant regeneration were first reported in Picea abies, using zygotic embryos as explants (Chalupa, 1985;

* Author for correspondence 
Hakman et al., 1985) and by the induction of somatic embryogenesis from megagametophytes in Larix decidua (Nagmani \& Bonga, 1985).

Plant regeneration via somatic embryogenesis can be divided into four steps: (I) initiation of somatic embryos from the primary explant, (II) proliferation of embryogenic cultures, (III) maturation of somatic embryos and (IV) regeneration of plants from somatic embryos (von Arnold et al., 1996). In conifers, several factors affect the induction frequency of embryogenic cultures. These include influence of the genotype, effect of the stage of development, and induction potential of the culture medium (Radojevic et al., 1999), particulary of sucrose, nitrogen level and composition, mineral elements, agar, plant growth regulators, and $\mathrm{pH}$ (Tautorus et al., 1991).

The maturation of conifer somatic embryos occurs in the presence of abscisic acid (ABA) and an osmotic agent (Attree \& Fowke, 1993). ABA inhibits cleavage polyembryony, thus allowing embryo singulation, further development, and maturation. Furthermore, ABA is involved in the accumulation of storage proteins (Dunstan et al., 1998), celular expansion control (Gutmann et al., 1996) and triacylglycerol biosynthesis (Attree et al., 1992). The effectiveness of the ABA treatment may be enhanced by an increase in the osmotic level of the culture medium by the addition of hexose sugars, sugar alcohols, or neutral polymers such as polyethylene glycol (Bonga et al., 1995). Previous studies in somatic embryogenesis of $A$. angustifolia were performed by Guerra \& Kemper (1992). The induction, establishment and the multiplication of embryogenic cultures, as well the effects of abscisic acid and osmotic agents on the maturation of these cultures were reported by Astarita \& Guerra (1998), Guerra et al. (2000), and Astarita \& Guerra (2000). However, Guerra et al., (2000) did not obtain the development of mature somatic embryos. It is important to consider that the Araucariaceae family shows, when compared to other conifer species, unique early zygotic embryogenic features (Kaur \& Bhatnagar, 1983), showing high degree of specialization (Buchholz, 1920). Furthermore, seeds of A. angustifolia are recalcitrant (Farrant et al., 1989) and most of the conifer seeds are orthodox (Attree \& Fowke, 1993). These features should be taken into account in order to develop a specific somatic embryogenesis protocol for the mass clonal propagation of $A$. angustifolia.
Thus, the purpose of the present work was: a) to study the effects of medium culture, mother tree genotype and the explant developmental stage on the induction rates of embryogenic cultures of $A$. angustifolia; b) to study the effects of different types and levels of growth regulators, osmotic agents, and carbohydrates and derived in the development and maturation of somatic embryos.

\section{MATERIAL AND METHODS}

\section{Plant material}

Immature cones of $A$. angustifolia were collected every fifteen days, from November, 1998 to February, 1999 from three open-pollinated trees (plants A, B, C), grown in natural populations in the highlands of Santa Catarina State, South of Brazil.

\section{Culture medium}

Two basal culture media were used: BM (Gupta \& Pullman, 1991) and LP (von Arnold \& Eriksson, 1981). BM culture medium consisted of BM basal salts supplemented with $0.5 \quad \mathrm{mg} . \mathrm{L}^{-1}$ pyridoxine.HCL, $0.5 \mathrm{mg} . \mathrm{L}^{-1}$ nicotinic acid, 1 mg. $\mathrm{L}^{-1}$ thiamine.HCL, $2 \mathrm{mg} . \mathrm{L}^{-1}$ glycine, $500 \mathrm{mg} . \mathrm{L}^{-}$ ${ }_{1}$ casein hydrolysate, 1 g. $\mathrm{L}^{-1}$ myo-inositol, 1 g.L. $\mathrm{L}^{-1}$ L-glutamine, 30 g.L . $^{-1}$ sucrose and 2 g.L L $^{-1}$ Phytagel $\left(\right.$ Sigma $\left.^{\circledR}\right)$. LP culture medium consisted of LP basal salts supplemented with $0.5 \mathrm{mg} . \mathrm{L}^{-1}$ pyridoxine.HCL, $0.5 \mathrm{mg} . \mathrm{L}^{-1}$ nicotinic acid, 1 mg. $\mathrm{L}^{-1}$ thiamine.HCL, $2 \mathrm{mg} . \mathrm{L}^{-1}$ glycine, $500 \mathrm{mg} . \mathrm{L}^{-}$ ${ }^{1}$ casein hydrolysate, $100 \mathrm{mg} . \mathrm{L}^{-1}$ myo-inositol, 450

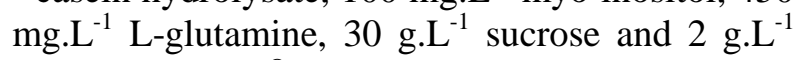
Phytagel $\left(\right.$ Sigma $\left.^{\circledR}\right)$. The $\mathrm{pH}$ of the culture medium was adjusted to 5.8 with $\mathrm{NaOH}$ and $\mathrm{HCl}$ before Phytagel was added. The media were sterilized by autoclaving at $121^{\circ} \mathrm{C}$ for $15 \mathrm{~min}$. Stock solutions of vitamins, L-glutamine, casein hydrolysate, myo-inositol, abscisic acid (ABA) and bovine serum albumin (BSA) were filter sterilized and added to the media after autoclaving.

\section{Induction of embryogenic cultures}

Seeds were removed from the cones and surface sterilized in $70 \%$ ethanol ( $2 \mathrm{~min}$ ), and $2 \%$ sodium hipoclorite $(10 \mathrm{~min})$, followed by rinsing three times with sterile water. Explants were dominant and non-dominant zygotic embryos (Figure 1A) excised from immature seeds under a stereoscope and inoculated in Petri dishes $(100 \times 15 \mathrm{~mm})$ 
containing $20 \mathrm{~mL}$ of culture medium consisting of the following treatments: 1) BM culture medium free of growth regulators $\left.\left(\mathrm{BM}_{0}\right) ; 2\right) \mathrm{BM}$ culture medium supplemented with $5 \mu \mathrm{M} \quad 2,4-$ dichlorophenoxyacetic acid (2,4-D), $2 \mu \mathrm{M}$ benzylaminopurine (BA) and $2 \mu \mathrm{M}$ kinetin (Kin) $\left(\mathrm{BM}_{5}\right)$; 3) LP culture medium free of growth regulators $\left(\mathrm{LP}_{0}\right)$; 4) $\mathrm{LP}$ culture medium supplemented with $5 \mu \mathrm{M}$ 2,4-D, $2 \mu \mathrm{M}$ BA and 2 $\mu \mathrm{M}$ Kin $\left(\mathrm{LP}_{5}\right)$. The cultures were incubated in the dark at $25 \pm 2{ }^{\circ} \mathrm{C}$. After thirty days the induction rates were recorded as affected by the culture medium composition, the genotype of mother tree and the developmental stage of the explants. Embryogenic cultures (Figure 1B) were identified by morphological characteristics and by the double staining procedure as described by Gupta \& Durzan (1987). Five repetitions of each treatment were employed, each repetition consisting by a Petri dish inoculated with nine zygotic embryos. A split plot statistical design was employed. The statistical procedures were based on the analysis of variance followed by the SNK test, both at the level of $5 \%$ of probability.

\section{Maintenance of embryogenic cultures}

Embryogenic cultures were maintained in continuous repetitive cell cycles by subculturing the embryogenic cultures every 20 days onto fresh semi-solid and liquid medium. Ten to twelve embryogenic cultures with approximately $0.25 \mathrm{~g}$ (fresh weight) were maintained onto Petri dishes $(100 \times 15 \mathrm{~mm})$ containing $20 \mathrm{~mL}$ of semi-solid culture medium and incubated in the dark at $25 \pm$ $2^{\circ} \mathrm{C}$. Suspensions cells were established utilizing $0.25 \mathrm{~g}$ (fresh weight) embryogenic culture inoculated in adapted nipple-flasks containing 120 $\mathrm{mL}$ of liquid medium incubated on a shaker (1 $\mathrm{rpm})$ in the dark at $25 \pm 2{ }^{\circ} \mathrm{C}$. Embryogenic cultures induced in culture medium with growth regulators were maintained on BM or LP culture medium supplemented with $2 \mu \mathrm{M}$ 2,4-D, $1 \mu \mathrm{M}$ BA and $1 \mu \mathrm{M}$ Kin $\left(\mathrm{BM}_{2}\right.$ and $\mathrm{LP}_{2}$ culture medium respectively). Embryogenic cultures initiated in culture medium without growth regulators were maintained in the same culture medium as used in the induction phase $\left(\mathrm{BM}_{0}\right.$ and $\left.\mathrm{LP}_{0}\right)$.

\section{Maturation of somatic embryos}

Only embryogenic cultures maintained in the culture media $\mathrm{BM}_{0}$ and $\mathrm{BM}_{2}$ were utilized in this phase. For maturation experiments basal BM culture medium was supplemented with different types of growth regulators (ABA, BA, Kin), osmotic agents (polyethylene glycol 3350, polyethylene glycol 8000, BSA), carbohydrates and derived (maltose, inositol). In experiment 1, embryogenic cultures were cultured on basal culture medium supplemented with 0 and $1 \%$ inositol. After two weeks, these embryogenic cultures were transferred to medium supplemented with 0,30 and $60 \mu \mathrm{M}$ ABA and cultured during 20 days. In experiment 2 , the basal culture medium was supplemented with 0,3 and $6 \%$ polyethylene glycol 8000 (PEG 8000). After 20 days, these cultures were transferred to a culture medium supplemented with the same levels of PEG 8000 in the presence or absence of $60 \mu \mathrm{M} \mathrm{ABA}$ and cultured during 80 days (subcultured every 20 days). In experiment 3 , the basal culture medium was supplemented with $0.1,0.2$, and $0.3 \%$ BSA plus $1 \mu \mathrm{M}$ each BA and Kin. After 20 days, this cultures were transferred to culture medium supplemented with $2.5 \mu \mathrm{M}$ each BA and Kin and cultured during 20 days. Then the embryogenic cultures were transferred to a culture medium supplemented with $0,5,10$ and $15 \mu \mathrm{M}$ ABA plus $2,5 \mu \mathrm{M}$ each BA and Kin and cultured during 20 days. In experiment 4 , the basal culture medium was supplemented with four different combinations $0+0,3+3,6+6$ and $9+9 \%$ of maltose and polyethylene glycol 3350 (PEG 3350) plus $1 \mu \mathrm{M}$ each BA and Kin. Embryogenic cultures were maintained in this treatment during 80 days (subcultured every 20 days). Experiments were performed with three replicates per treatment. Three samples of $0,25 \mathrm{~g}$ of embryogenic cultures per Petri dish were cultured on $20 \mathrm{~mL}$ of each maturation medium (replication) and incubated at $25 \pm 2{ }^{\circ} \mathrm{C}$ in the dark.

\section{RESULTS}

\section{Induction of embryogenic cultures}

Effect of media: Statistical analysis did not show significant differences $(\mathrm{P}<5)$ between inductions rates in response to the four treatments tested (Table 1). The basal composition of the culture media evaluated and the presence or absence of growth regulators were not limiting factors for the induction of embryogenic cultures in $A$. angustifolia. 
Table 1 - Induction rates of embryogenic cultures of $A$. angustifolia from immature zygotic embryos inoculated on basal LP and BM culture medium supplemented or not with 2,4-D, BA and Kin.

\begin{tabular}{ccc}
\hline Culture & $\begin{array}{c}\text { Explant } \\
\text { Number }\end{array}$ & $\begin{array}{c}\text { Induction Rate } \\
(\%)\end{array}$ \\
\hline $\mathrm{BM}_{0}$ & 225 & $15.5 \mathrm{a}$ \\
$\mathrm{LP}_{5}$ & 225 & $15.1 \mathrm{a}$ \\
$\mathrm{BM}_{5}$ & 225 & $14.2 \mathrm{a}$ \\
$\mathrm{LP}_{0}$ & 225 & $14.2 \mathrm{a}$ \\
\hline
\end{tabular}

- Means followed by the different letters in the columm are significantly different at the 0.05 level according to SNK Test.

Effect of the developmental stage of the explant: The developmental stage of the explant considered as the cone harvest date influenced significantly $(\mathrm{P}<5)$ the induction rates of embryogenic culture in A. angustifolia (Table 2). The highest induction frequency of embryogenic cultures was obtained in the first harvest date $(23.3 \%)$ and with exeption of the second harvest date $(10.5 \%)$ a progressive decline in the induction rate was observed. From the third collection date, only non-dominant zygotic embryos were employed. However it was possible to obtain expressive induction rates in the third (05/01/99) and fourth (25/01/99) cone harvest date.

Table 2 - Induction rates of embryogenic cultures of $A$. angustifolia from immature zygotic embryos excised from seeds excised from female cones collected in different times.

\begin{tabular}{ccc}
\hline $\begin{array}{c}\text { Harvest } \\
\text { Date }\end{array}$ & $\begin{array}{c}\text { Explant } \\
\text { Number }\end{array}$ & $\begin{array}{c}\text { Induction Rate } \\
(\%)\end{array}$ \\
\hline $30 / 11 / 98$ & 180 & $23.3 \mathrm{a}$ \\
$05 / 01 / 99$ & 180 & $19.4 \mathrm{~b}$ \\
$25 / 01 / 99$ & 180 & $17.8 \mathrm{c}$ \\
$17 / 12 / 98$ & 180 & $10.5 \mathrm{~d}$ \\
$10 / 02 / 99$ & 180 & $2.8 \mathrm{e}$ \\
\hline
\end{tabular}

- Means followed by the different letters in the columm are significantly different at the 0.05 level according to SNK Test.

\section{Effect of mother tree:}

The genotype of the mother tree significantly influenced $(\mathrm{P}<5)$ the induction rates of embryogenic cultures (Table 3). Different rates of embryogenic induction were observed for the three mother tree selected, and genotype B showed the highest value (19.9\%).
Table 3. Effect of different genotypes on the induction rates of embryogenic cultures of $A$. angustifolia from immature zygotic embryos.

\begin{tabular}{ccc}
\hline Genotype & $\begin{array}{c}\text { Explant } \\
\text { Number }\end{array}$ & $\begin{array}{c}\text { Induction Rate } \\
(\%)\end{array}$ \\
\hline Plant B & 300 & $19.9 \mathrm{a}$ \\
Plant A & 300 & $14.9 \mathrm{~b}$ \\
Plant C & 300 & $9.3 \mathrm{c}$ \\
\hline
\end{tabular}

- Means followed by the different letters in the columm are significantly different at the 0.05 level according to SNK Test.

\section{Maintenance of embryogenic cultures}

During this phase, the patterns of embryogenic cultures maintained in the culture medium with or without growth regulators showed differences. Embryogenic cultures maintained in culture media supplemented with 2,4-D, BA and $\mathrm{Kin}\left(\mathrm{BM}_{2}\right.$ and $\mathrm{LP}_{2}$ ) were white-translucent (Figure 1C). Embryogenic cultures maintained in culture medium free of growth regulators $\left(\mathrm{BM}_{0}\right.$ and $\left.\mathrm{LP}_{0}\right)$ showed a progressive browning process (Figure 1D). However, in these cultures the presence of sectors with proliferative capacity was observed. These sectors were selected and subcultured on the same culture media composition. Independent of the presence or absence of growth regulators, it was possible to identify the somatic proembryos in the surface of the cultures. These somatic proembryos were bipolar, containing many small clusters of isodiametric cells (embryogenic region), from which elongated and vacuolated cells extended (suspensor region) (Figure 1E).

\section{Maturation of embryogenic cultures}

In the maturation phase, only the treatment containing maltose (6 and 9\%) and PEG 3350 (6 and $9 \%)$ plus BA and Kin $(1 \mu \mathrm{M}$ each) were effective for the progression of somatic proembryos to globular and torpedo stages (Figure $1 \mathrm{~F}$ and $1 \mathrm{G})$. Maturation medium supplemented with BSA $(0.1,0.2,0.3 \%)$ plus BA and Kin $(1 \mu \mathrm{M}$ each) allowed the organization of somatic embryos; however without further development. Use of inositol (1\%) and PEG 8000 (3 and 6\%) as osmotic agents did not result in a major degree of somatic embryo development and organization. Use of different levels of $\mathrm{ABA}(5,10,15,30$ and $60 \mu \mathrm{M})$ did not improve the formation and development of somatic embryos, and caused browning and necrosis of embryogenic cultures during continuous subcultures. 


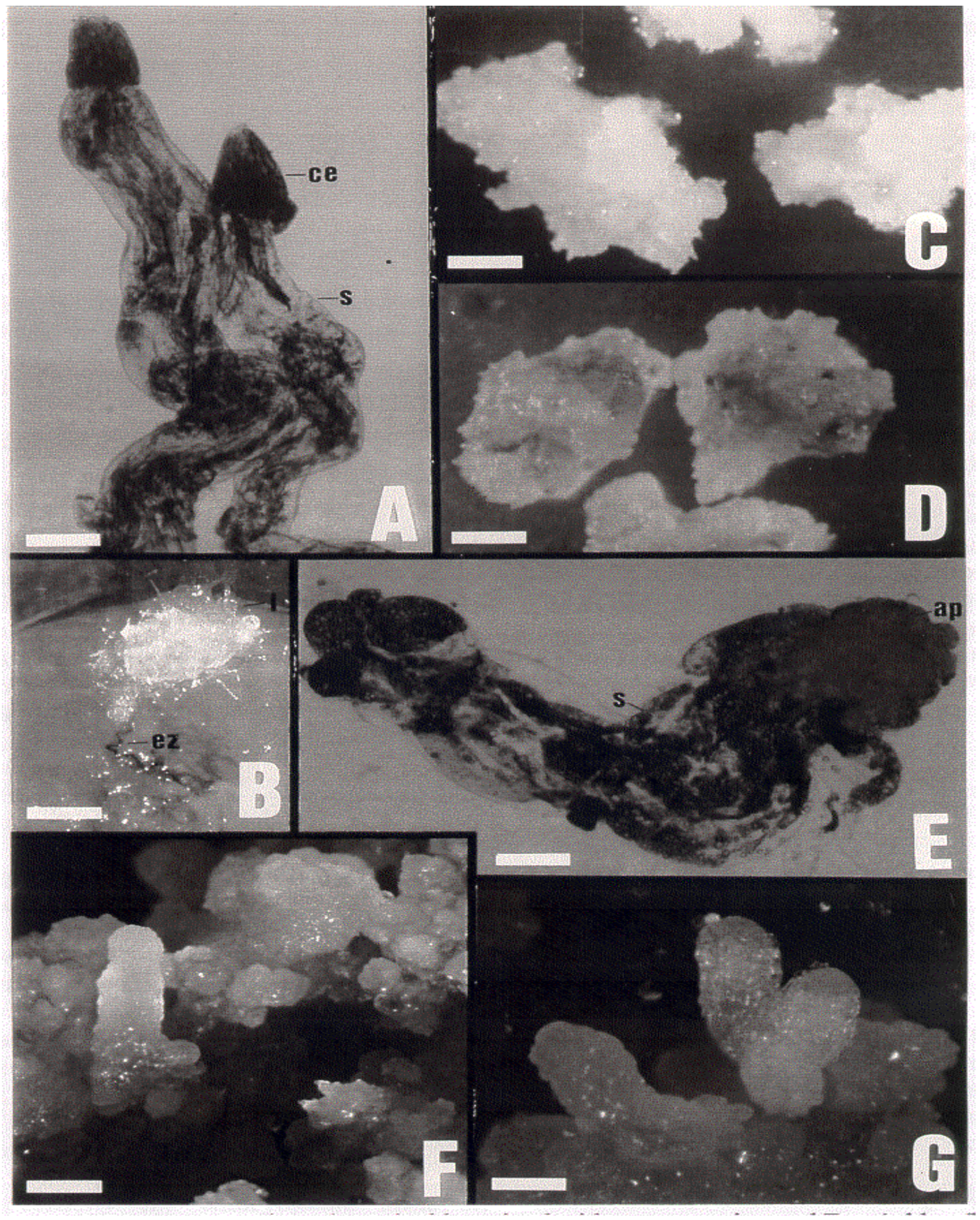

Figure 1. A) Isolated immature zygotic embryo double stained with acetocarmine and Evan's blue (bar: $115 \mu \mathrm{m})$. B) Induction of embryogenic culture on BM culture medium supplemented with 2,4-D (5 $\mu \mathrm{m})$, BA and Kin $(2 \mu \mathrm{M}$ each) (bar: $2 \mathrm{~mm}$ ). C) Embryogenic culture maintained on BM culture medium supplemented with 2,4-D (2 $\mu \mathrm{m})$, BA and Kin $(2 \mu \mathrm{M}$ each) (bar:1.77 mm). D) Embryogenic culture maintained on BM culture medium free of growth regulators (bar: $1.77 \mathrm{~mm}$ ). E) Somatic proembryo double stained with acetocarmine and Evan's blue (bar: $66.7 \mu \mathrm{m})$. F and G) Torpedo somatic embryos cultured on maturation treatment with maltose (6 and 9\%) and PEG 3350 (6 and 9\%) plus BA and Kin (1 $\mu \mathrm{M}$ each) (bar: $2.50 \mathrm{~mm}$, and $3.75 \mathrm{~mm}$, respectively). (ce) embryogenic complex; (s) suspensor; (i) embryogenic culture; (ez) zygotic embryo; (ap) embryogenic region. 


\section{DISCUSSION}

In our experiments, the induction rates of embryogenic cultures were affected by genotype of the mother tree and the cone collection time. Basal medium composition and the presence or absence of growth regulators did not influence the induction rates. In conifers, several reports have described the effect of the developmental explant stage in the induction rate of embryogenic cultures. In Pinus elliottii (Jain et al., 1989), P. taeda (Li \& Huang, 1996), Abies alba x Abies cephalonica (Salajova et al., 1996) and Cryptomeria japonica (Ogita et al., 1999) differences in the induction frequency of embryogenic cultures were dependent on the developmental stage of the explants. In $A$. angustifolia inductive embryogenic ability of zygotic pre-cotyledonary embryos is restricted to a period from December to February, disappearing when cotyledon development progresses (Astarita \& Guerra, 1998). For Picea glauca, during maturation of the zygotic embryo considerable changes occur in its biochemical characteristics and this appears to correlate with the ability of embryo explants to initiate somatic embryogenesis (Park et al., 1993). In our experiments, the use of non-dominant immature zygotic embryos offered considerable initiation rate although the dominant zygotic embryo was in late developmental stage.

This strategy represents an alternative to obtain genetically distinct embryogenic cultures. In $A$. angustifolia only simple polyembryony occurs, and therefore zygotic proembryos are heterogenics (Dogra, 1978). If somatic embryogenesis provides only a few genotypes, a serious loss of genetic diversity would occur in the operational "breedingcloning" programs (Park et al., 1993). For A. angustifolia, this is a critical point since this species has undergone continuous declines in the extent of its occurrence.

Genotype specificity for embryogenic initiation occurs in conifers (Attree \& Fowke, 1993). In our experiments, differences was observed between genotypes tested up to $10.6 \%$ in the induction rate. For A. angustifolia, on the same conditions of culture medium, difference up to $29.2 \%$ was observed in the initiation rate of embryogenic cultures (Guerra et al., 2000). In Pinus strobus, initiation rates varying from $2.6 \%$ to $23 \%$ were obtained (Garin et al., 1998). According to von Arnold et al. (1995), the quality of the seeds and the genotype employed might affect the induction rates of somatic embryogenesis. In Picea glauca, significant variances due to families and family $\mathrm{x}$ treatment interactions were found (Högberg et al., 1998).

In $A$. angustifolia, different levels of 2,4-D, NAA, $\mathrm{BA}$, and Kin were tested in order to establish embryogenic cultures (Guerra at al., 2000). Astarita \& Guerra (1998) obtained induction frequencies up to $68.7 \%$ when immature zygotic embryos were inoculated in basal medium LP supplemented with 2,4-D, BA and Kin. However, a significant part of the generated cell lines did not survive to the gradual reduction of growth regulators levels in the maintenance phase. In our experiments, the choice for low levels of growth regulators in the initiation phase allowed the establishment and continuous subculture in most of the induced embryogenic cultures. Furthermore, it was possible to induct and establish the embryogenic cultures in culture medium free of growth regulators. In $A$. angustifolia, the cell proliferation in culture medium free of growth regulators can be a requisite for the subsequent embryonic development (Guerra et al., 2000). It has been suggested that the presence of auxin in the culture medium influenced the formation of non polar proembryos affecting the development of somatic embryos in the maturation phase (Korlach \& Zoglauer, 1995). In Pinus sylvestris, all developmental stages of somatic embryogenesis were observed in culture medium free of growth regulators (Lelu et al., 1999).

In the present experiment during the maintenance phase the cell browning and the rapid loss of embryogenic capacity of the embryogenic cultures in the culture medium free of growth regulators was evident. This suggested an intensive cell selection process imposed by the culture environment, even considering the presence of specific sector with cell proliferation. In embryogenic cultures with growth regulators the same effect was only observed when the subculture interval exceeded 30 days. In Picea rubens the subcultures intervals longer than 21 days resulted in the same effect (Harry \& Thorpe, 1991). However, the cell browning neither affected the grown rate in the maintenance phase nor its ability to produce embryos (Isabel \& Tremblay, 1995).

In the present experiment during the maturation phase only treatments with maltose (6 and 9\%) and PEG 3350 (6 and 9\%) plus BA and Kin $(1 \mu \mathrm{M}$ each) allowed the progression to globular and torpedo somatic embryos. Use of maltose as 
osmotic agent or carbohydrate source during maturation phase has been demonstrated beneficial in conifer somatic embryogenesis. Maltose combined with ABA promoted and/or enhanced development of mature somatic embryos in Abies alba (Hristoforoglu et al., 1995), Pinus taeda (Li et al., 1998) and Pinus nigra (Salajova et al., 1999).

Up to now, the strategies used for the progression and maturation of somatic embryos of $A$. angustifolia, in similar way to that reported for most of the conifers systems are based on the use of different levels of ABA, carbohydrates sources, and osmotic agents (Guerra et al., 2000). Astarita \& Guerra (1998) showed that maturation treatments with sucrose and fructose supported the cell growth but did not improve the formation of somatic embryos regardless the addition of $\mathrm{ABA}$ (38 $\mu \mathrm{M})$. When the culture medium was supplemented with PEG 8000 (1\%) or ABA (7 and $19 \mu \mathrm{M})$ the development of somatic proembryos was enhanced. The culture medium supplemented with ABA $(50 \mu \mathrm{M})$ and PEG $4000(1 \%)$ resulted in the development of globular and torpedo somatic embryos after ninety days in culture, but no further development for cotyledonary stage was observed (Guerra et al., 2000). However, in our experiments use of $\mathrm{ABA}$ and $\mathrm{ABA}$ associated with osmotic agents were not effective in development and progression of somatic embryos.

Probably, the model of development of $A$. angustifolia zygotic embryogenesis influenced these results. In Araucariaceae, during the early zygotic embryogeny, the lowermost cells do not contribute to the embryo formation, but are associated with the cap organization (Haines \& Prakash, 1980). The function of the proembryo cap has been a matter of speculation; one hypotesis is that thick walls of the cap prevent cleavage polyembryony (Astarita \& Guerra, 2000). Our working hypothesis is that at the morphological level ABA was not required in earlier stages of proembryo zygotic development (cleavage polyembryony inibition) and therefore, somatic proembryos did not respond to initial maturation treatments with $\mathrm{ABA}$. However, in late stage zygotic embryo development, ABA may exert some influences. In embryonic axes of mature seeds of $A$. angustifolia the presence of dehydrinlike proteins (LEA homologues) was shown and this was associated with high ABA contents (Farrant et al., 1996). In Picea glauca, higher ABA content in the zygotic proembryo occured concomitantly with the decrease of the $\mathrm{ABA}$ content in the megagametophyte and preceded storage reserves deposition (Carrier et al., 1999).

Seeds of $A$. angustifolia are recalcitrant type. Cycad embryos (Ceratozamia) are recalcitrant and they do not appear to respond to treatment with either ABA or high levels of osmoticals (Litz et al., 1995). In Podocarpus henkelii, a conifer species with recalcitrant seeds, the pattern and the type of reserve accumulation in the seed suggested a strategy of maintenance of full metabolic competence for continuous development without the intervention of drying and developmental arrest that occur in orthodox seeds (Dodd et al., 1989). According to Litz et al. (1997), normal maturation and germination of somatic embryos of tropical and subtropical trees can be obtained only by understanding the storage characteristics of their seeds, i.e. recalcitrant versus orthodox types. Knowledge of their aspects could aid in the development of more precise and less empirically based $A$. angustifolia somatic embryogenesis protocol.

In conclusion, the results of the present work demonstrated that embryogenic culture induction in $A$. angustifolia was dependent of the developmental stage of the explant and genotype of the mother tree. The basal medium composition and the presence or absence of growth regulators did not influence the induction frequency. In the maintenance phase, cell browning and loss of embryogenic capacity of the embryogenic cultures in the culture medium free of growth regulators was observed. However, independent of the presence or absence of growth regulators, the development of bipolar somatic proembryos was observed. In the maturation phase, the culture medium supplemented with maltose (6 and 9\%) and PEG 3350 (6 and 9\%) plus BA and Kin $(1 \mu \mathrm{M}$ each) promoted the progression of somatic proembryos to globular and torpedo stages.

\section{ACKNOWLEDGEMENTS}

The authors are thankful to Agronomist Msc. Sadi Nazareno de Souza and Agronomist João Antônio Zanata from EPAGRI for providing developing $A$. angustifolia cones. Financial support was provided by CNPq and PADCT/MCT. 


\section{RESUMO}

Culturas embriogênicas de $A$. angustifolia foram induzidas a partir de embriões zigóticos dominantes e não-dominantes excisados de sementes imaturas provenientes de três diferentes genótipos, em cinco datas de coleta. Os embriões zigóticos foram inoculados em meio de cultura LP e BM suplementados ou não com 2,4-D $(5 \mu \mathrm{M})$, BA $(2 \mu \mathrm{M})$ e Kin $(2 \mu \mathrm{M})$. O genótipo da planta doadora e o estádio de desenvolvimento do explante influenciaram significativamente a frequiência de indução. Na fase de manutenção, as culturas embriogênicas foram mantidas em ciclos contínuos de subcultivo a cada 20 dias em meios semi-sólidos ou líquidos. Na fase de maturação, foram testados fontes e níveis de fitorreguladores, agentes osmóticos, carboidratos e derivados. Meios de cultura suplementados com PEG 3350 (6 e 9\%), maltose (6 e 9\%), BA e Kin (1 $\mu \mathrm{M}$ cada) foram efetivos no desenvolvimento de embriões somáticos nos estádios globular e torpedo.

\section{REFERENCES}

Astarita, L.V. and Guerra, M. P. (1998), Early somatic embryogenesis in A. angustifolia - induction and maintenance of embryonal-suspensor mass cultures. Brazilian Journal of Plant Physiology. 10, 113-118.

Astarita, L.V. and Guerra, M. P. (2000), Conditioning of culture medium by suspension cells and formation of somatic proembryo in Araucaria angustifolia (Coniferae), In Vitro Cell. Dev. Biol.-Plant. 36, 194200.

Attree, S. M.; Pomeroy, M. K., and Fowke, L. C. (1992), Manipulation of conditions for the culture of somatic embryos of white spruce for improved triacylglycerol biosynthesis and desiccation tolerance. Planta. 187, 395-404.

Attree, S. M. and Fowke, L. C. (1993), Embryogeny of gymnosperms: advances in synthetic seed technology of conifers. Plant Cell, Tissue and Organ Culture. 35, $1-35$.

Bonga, J. M.; Klimaszewska, K.; Lelu, M. A. and von Aderkas, P. (1995), Somatic embryogenesis in Larix. In-Somatic Embryogenesis in Woody Plants, eds. S. Jain, P. Gupta \& R. Newton. Kluwer Academic Publishers, Dordrecht, v. 3, pp. 315-340.

Buchholz, J. T. (1920), Embryo development and polyembryony in relation to the phylogeny of conifers. American Journal of Botany. 7, 125-145.
Carrier, D. J.; Kendall, E. J.; Bock, C. A.; Cunningham, J. E., and Dunstan, D. I. (1999), Water content, lipid deposition, and (+)-abscisic acid content in developing white spruce seeds. Journal of Experimental Botany. 50, 1359-1364.

Chalupa,V. (1985), Somatic embryogenesis and plant regeneration from cultured immature and mature embryosof Picea abies (L.) Karst. Comm. Inst. For. Cechosloveniae. 14, 57-63.

Dodd, M. C.; Van Staden, J. and Smith, M. (1989), Seed development in Podocarpus henkelii: an ultrastructural and biochemical study. Annals of Botany. 64, 297-310.

Dogra, P. D. (1978), Morphology, development and nomenclature of conifer embryo. Phytomorphology. 28, 307-322.

Dong, J. Z. and Dunstan, D. I. (1999), Cloning and characterisation of six embryogenesis-associated cDNAs from somatic embryos of Picea glauca and their comparative expression during zygotic embryogenesis. Plant Molecular Biology. 39, 859864.

Dunstan, D. I.; Dong, J.Z.; Carrier, D. J. and Abrams, S. R. (1998), Events following ABA treatment of spruce somatic embryos, In Vitro Cell. Dev. Biol.-Plant. 34, 159-168.

Farrant, J. M.; Pammenter, N. W. and Berjak, P. (1989), Germination associated events and the desiccation sensitivity of recalcitrant seeds: a study on three unrelated species. Planta. 178, 189-198.

Farrant, J. M.; Pammenter, N. W.; Berjak, P.; Farnsworth, E. J. and Vertucci, C. W. (1996), Presence of dehydrin-like proteins and levels of abscisic acid in recalcitrant (desiccation sensitive) seeds may be related to habitat. Seed Science Research. 6, 175-182.

Garin, E.; Isabel, N. and Plourde, A. (1998), Screening of large numbers of seed families of Pinus strobus L. for somatic embryogenesis from immature and mature zygotic embryos. Plant Cell Reports. 18, 3743.

Guerra, M. P. and Kemper, E. (1992), Tecnologias futuras: aplicação da poliembriogênese somática para a propagação massal de plantas elite de Araucaria angustifolia (Bert) O Ktze. In-Anais do Congresso Nacional Sobre Essências Florestais, São Paulo, pp. 1233-1236.

Guerra, M. P.; Reis, M. S.; Scheinede, L. and Silveira, V. (1999), Inventário dos Recursos Florestais da Mata Atlântica - Araucaria angustifolia (Bert.) O. Kuntze. Conselho Nacional da Reserva da Biosfera da Mata Atlântica, São Paulo, pp. 135.

Guerra, M. P.; Silveira, V.; Santos, A. L. W.; Astarita, L. V. and Nodari, R.O. (2000), Somatic embryogenesis in Araucaria angustifolia (Bert) O. Ktze. In-Somatic embryogenesis in woody plants, eds. S. Jain, P. Gupta \& R. Newton. Kluwer Academic Publishers, Dordrecht, v. 6, pp. 457-478. 
Gupta, P. K. and Durzan, D. J. (1987), Biotechnology of somatic polyembryogenesis and plantlet regeneration in loblolly pine. Bio/Technology. 5, 147151.

Gupta, P. K., and Pullman, G. (1991), Method for reproducing coniferous plants by somatic embryogenesis using abscisic acid and osmotic potential variation, U.S. Patent No. 5,036,007.

Gutmann, M.; von Aderkas, P.; Label, P. and Lelu, M. A. (1996), Effects of abscisic acid on somatic embryo maturation of hybrid larch. Journal of Experimental Botany. 47, 1905-1917.

Haines, R. J. and Prakasha, N. (1980), Proembryo development and suspensor elongation in Araucaria juss. Australian Journal of Botany. 28, 511-522.

Hakman, I.; Fowke, L.; von Arnold, S. and Eriksson, T. (1985), The development of somatic embryos in tissue cultures initiated from immature embryos of Picea abies (Norway spruce), Plant Science. 38, 5359.

Harry, I. S. and Thorpe, T. A. (1991), Somatic embryogenesis and plant regeneration from mature zygotic embryos of red spruce. Bot. Gaz., 152, 446452.

Högberg, K.A., Ekberg, I., Norell, L. \& von Arnold, S. (1998), Integration of somatic embryogenesis in a tree breeding programe: a case study with Picea abies. Canadian Journal of Forest Research., 28, 1536-1545.

Hristoforoglu, K., Schimidt, J., \& Nordenkampf, H.B. (1995), Development and germination of Abies alba somatic embryos. Plant Cell, Tissue and Organ Culture., 40, 277-284.

Isabel, N. and Tremblay, F. M. (1995), Somatic embryogenes in red spruce (Picea rubens Sarg), InSomatic Embryogenesis in Woody Plants, eds. S. Jain, P. Gupta \& R. Newton. Kluwer Academic Publishers, Dordrecht, v. 3, pp. 111-123.

Jain, S. M., Dong, N. and Newton, R. J. (1989), Somatic embryogenesis in slash pine (Pinus elliottii) from immature embryos cultured in vitro. Plant Science. 65, 233-241.

Kaur, D. and Bhatnagar, S. P. (1983), Studies in the family Araucariaceae. Beitr. Biol. Pflanzen. 58, 369381.

Korlach, J. and Zoglauer, K. (1995), Developmental patterns during direct somatic embryogenesis in protoplasts culture of european larch (Larix decidua Mill.), Plant Cell Reports. 15, 242-247.

Lelu, M. A.; Bastien, C.; Drugeault, A.; Gouez, M. L. and Klimaszewska, K. (1999), Somatic embryogenesis and plantlet development in Pinus sylvestris and Pinus pinaster on medium with and without growth regulators. Physiologia Plantarum., 105, 719-728.

Li, X. Y. and Huang, F. H. (1996), Induction of somatic embryogenesis in loblolly pine (Pinus taeda L.), In Vitro Cell. Dev. Biol.-Plant. 32, 129-135.
Li, X. Y., Huang, F. H. and Gbur, E. E. (1998), Effect of basal medium, gorwth regulators and phytagel concentration on initiation of embryogenic cultures from immature zygotic embryos of loblolly pine (Pinus taeda L.), Plant Cell Reports. 17, 298-301.

Lima, A. R. and Capobianco, J. P. R. (1997), Mata atlântica: avanços legais e institucionais para sua conservação. Instituto Socioambiental, Brasília.

Litz, R. E.; Chavez, V. M. and Moon, P. A. (1995), Somatic embryogenesis in the Cycadales. In-Somatic embryogenesis in woody plants, eds. S. Jain, P. Gupta \& R. Newton. Kluwer Academic Publishers, Dordrecht, v. 3, pp. 1-15.

Litz, R. E.; Chavez, V. M. and Moon, P. A. (1997), Induction of embryogenic cultures from mature-phase tropical and subtropical trees and control of somatic embryo maturation and germination. In-Proceedings of Recent Advances in Biotechnology for Tree Conservation and Management, Florianópolis, pp. 232-243.

Nagmani, R. and Bonga, J. M. (1985), Embryogenesis in subcultured callus of Larix decidua. Canadian Journal of Forest Research., 15, 1088-1091.

Ogita, S., Ishikawa, H., and Kubo, T. (1999), Somatic embryogenesis from immature and mature zygotic embryos of Cryptomeria japonica I: Embryogenic cell induction and its morphological characteristics. $J$. Wood Sci., 45, 87-91.

Park, Y. S., Pond, S. E., and Bonga, J. M. (1993), Initiation of somatic embryogenesis in white spruce (Picea glauca): genetic control, culture treatment effects, and implications for tree breeding. Theor. Appl. Genet., 86, 427-436.

Radojevic, L., Älvarez, C., Fraga, M. F. and Rodríguez, R. (1999), Somatic embryogenic tissue establishment from mature Pinus nigra Arn. ssp. Salzmannii embryos. In Vitro Cell. Dev. Biol.-Plant., 35, 206209.

Salajova, T.; Jasik, J.; Kormutak, A.; Salaj, J. and Hakman, I. (1996), Embryogenic culture initiation and somatic embryo development in hybrid firs (Abies alba x Abies cephalonica, and Abies alba $\mathrm{x}$ Abies numidica), Plant Cell Reports., 15, 527-530.

Salajova, T., Salaj, J., and Kormutak, A. (1999), Initiation of embryogenic tissues and plant regeneration from somatic embryos of Pinus nigra Arn. Plant Science., 145, 33-40.

Tautorus, T. E., Fowke, L. C. and Dunstan, D. I. (1991), Somatic embryogenesis in conifers. Canadian Journal of Botany., 69, 1873-1899.

von Arnold, S. and Eriksson, T. (1981), In vitro studies of adventitious shoot formation in Pinus contorta. Canadian Journal of Botany., 59, 870-874.

von Arnold, S.; Clapham, D.; Egertsdotter, U. and Mo, L.H. (1996), Somatic embryogenesis in conifers - a case study of induction and development of somatic embryos in Picea abies. Plant Growth Regulation., 20, 3-9. 
von Arnold, S.; Egertsdotter, U.; Ekberg, I.; Gupta, P., Mo, H. and Nörgaard, J. (1995), Somatic embryogenesis in norway spruce (Picea abies), InSomatic embryogenesis in woody plants, eds. S. Jain, P. Gupta \& R. Newton. Kluwer Academic Publishers, Dordrecht, v. 3, pp. 17-36.
Received: December 11, 2000; Revised: May 11, 2001; Accepted: July 26, 2001. 